\title{
A STUDY OF THE MECHANISM BY WHICH EXERCISE INCREASES THE PULMONARY DIFFUSING CAPACITY FOR CARBON MONOXIDE* $\dagger$
}

\author{
By JOSEPH C. ROSS, $\ddagger$ REGINA FRAYSER AND JOHN B. HICKAM
}

(From the Department of Medicine, Indiana University School of Medicine, Indianapolis, Ind.,
and the Department of Medicine, Duke University School of Medicine, Durham, N. C.)

(Submitted for publication October 6, 1958; accepted February 12, 1959)

The pulmonary diffusing capacity $\left(D_{L}\right)$ increases with exercise. This was first shown by Krogh in 1915 (1) and has been confirmed by investigators who have studied the matter since that time, using both carbon monoxide and oxygen (2-5). The mechanism by which exercise increases the diffusing capacity is not altogether clear, however, and the apparent amount of increase with exercise is dependent on the technique used for determining the diffusing capacity, and on the severity of the exercise.

Two methods widely used for estimating the pulmonary diffusing capacity for carbon monoxide are the steady state method of Filley, MacIntosh and Wright (3) and the Krogh breath holding technique as modified by Ogilvie, Forster, Blakemore and Morton (5). In the steady state technique, the subject breathes continuously throughout the test period, which makes minute ventilation a variable factor. In the breath holding method, however, the breath is held and minute ventilation cannot be a variable factor during the actual test period.

The present study was undertaken to investigate the cause of the increased pulmonary diffusing capacity for carbon monoxide which occurs with exercise, using both the steady state and the breath holding techniques. Both methods were used in this study because both have been widely employed for the measurement of diffusing capacity and both show an increase in diffusing capacity with exercise, but the conditions of

* This investigation was supported (in part) by a research grant (Public Health Service H-4080) from the National Heart Institute of the National Institutes of Health, Public Health Service, (in part) by the American Heart Association, and (in part) by the Life Insurance Medical Research Fund.

$\dagger$ This paper was presented at the Fiftieth Annual Meeting of the American Society for Clinical Investigation, Atlantic City, N. J., May 5, 1958.

$\ddagger$ United States Public Health Service Postdoctorate Research Fellow. measurement are different enough to indicate that results with one of these methods might serve as a useful check on the reliability of conclusions reached by the use of the other method. The effects of altering pulmonary blood flow, ventilation, pulmonary vascular pressures, blood $\mathrm{pH}$ and blood gas contents, either alone or in combinations, have been studied in an attempt to simulate some of the physiological effects of exercise which might conceivably alter the diffusing capacity. The results indicate that the factors apparently responsible for the increase in pulmonary diffusing capacity with exercise may differ with the technique used.

\section{METHODS}

Subjects. The subjects studied were normal, male, graduate and medical students with an age range of 21 to 26 years and surface area range of 1.70 to $2.14 \mathrm{M.}^{2}$. All were able to carry out the experimental procedures without difficulty.

Diffusing capacity of the lung for carbon monoxide $\left(D_{L}\right)$. a) Steady state technique. Steady state determinations of the pulmonary diffusing capacity were made by the method of Filley and co-workers (3). An indwelling brachial artery needle, and, in those subjects where cardiac output was measured, a superior vena cava catheter, were inserted and the subject was allowed to lie quietly for 30 minutes before the studies were begun. He then inspired 0.1 per cent carbon monoxide in air through a Krogh valve for six minutes and the sample for measurement of $D_{L}$ was collected during the last two minutes. For determination of $D_{L}$ during exercise, the subject inspired air for the first two minutes and the 0.1 per cent carbon monoxide mixture for the last four minutes of the six minute period, with sample collection during the last two minutes. Expired gas was collected in a Douglas bag during the fifth and sixth minutes and the number of expirations for this two minute period was recorded. Injection of the T-1824 dye and collection of arterial blood samples at two second intervals for cardiac output determination were carried out as close to the initial part of the two minute collection period as was possible. This usually required 30 to 40 seconds. An arterial blood sample for the determination of $\mathrm{pCO}_{2}$ was then withdrawn at a slow, regular rate into a heparinized syringe over the two minute period while expired gas was being collected. 
Only one exercise determination and a total of no more than three $D_{\mathbf{L}}$ determinations were made in a single subject on any one day. The subject rested at least 20 minutes between each determination of $\mathrm{D}_{\mathbf{L}}$. Control studies in two subjects at rest showed no marked tendency for $D_{L}$ to decrease progressively as the result of repeated measurements under these conditions. The successive values for $D_{\mathrm{L}}$ obtained with intervening recovery periods of $20 \mathrm{~min}$ utes were: for Subject D. G., 27.4, 26.9 and $25.0 \mathrm{ml}$. CO per minute per mm. Hg; and for Subject J. M., 33.1, 33.8, 33.0 and $32.6 \mathrm{ml}$. CO per minute per $\mathrm{mm}$. $\mathrm{Hg}$. This result indicated that the change in $D_{L}$ caused by repeated measurements under these conditions would be small relative to the change produced by exercise. Because the emphasis in this study was on factors which cause a change in the diffusing capacity, rather than on the absolute value of the diffusing capacity, no attempt was made to correct for "back pressure" of carbon monoxide in the pulmonary capillary blood. The order in which $D_{L}$ under different conditions was measured was randomized from subject to subject in order to minimize systematic error resulting from repeated measurement.

The volume of expired gas was measured in a Tissot gasometer and corrected to the volume at standard temperature and pressure, dry (S. T. P. D.). The expired gas was analyzed, immediately after collection, for carbon monoxide in an infrared analyzer ${ }^{1}$ which gave results reproducible to 0.001 per cent carbon monoxide over the concentration range in use $(0.000$ to 0.100 per cent carbon monoxide). Gas samples for carbon dioxide and oxygen analysis were removed from the Douglas bag immediately after collection and stored over mercury in glass tonometers for analysis within four hours in the micro-Scholander apparatus. Analyses were done in duplicate and required to check within 0.1 per cent. The $\mathrm{pH}$ of whole blood was measured with a Cambridge Model $\mathrm{R} \mathrm{pH}$ meter equipped with an enclosed glass electrode. Measurements were made at room temperature, usually 25 to $26^{\circ} \mathrm{C}$., and the result was corrected to $37^{\circ} \mathrm{C}$. by Rosenthal's factor (6). The per cent oxygen saturation of arterial blood was assumed to be 97 per cent for calculation of $\mathrm{pCO}_{2}$ by nomogram. The arterial blood oxygen capacity was estimated from the total hemoglobin, which was determined by the spectrophotometric method of Drabkin and Austin (7). The carbon dioxide content of whole blood was determined by the method of Van Slyke and Neill (8), and duplicate analyses were required to check within 0.1 volume per cent. The plasma carbon dioxide content was estimated from the blood carbon dioxide content and from the $\mathrm{pH}$, hemoglobin concentration and per cent oxygen saturation by the line charts of Van Slyke and Sendroy (9). The plasma $\mathrm{CO}_{2}$ tension was calculated by the Henderson-Hasselbalch equation, using a $\mathrm{pK}^{\prime}$ of 6.11 (10). In this laboratory, $\mathrm{pCO}_{2}$ values by this method are reproducible to within $\pm 1.0 \mathrm{~mm}$. $\mathrm{Hg}$.

Calculations of $D_{L}$ were made as outlined by Filley and co-workers (3):

$$
\dot{\mathrm{V}}_{\mathrm{CO}}=\dot{\mathrm{V}}_{\mathrm{E}}\left(\mathrm{FI}_{\mathrm{CO}} \frac{\mathrm{FE}_{\mathrm{N}_{2}}}{\mathrm{FI}_{\mathrm{I}_{2}}}-\mathrm{FE}_{\mathrm{CO}}\right)
$$

${ }^{1}$ Model 15A, Liston Becker Co. and

$$
P_{A C O}=(B p-47) \frac{F E_{C O}-r F_{C O}}{1-r}
$$

where

$$
\begin{gathered}
r=\frac{V d^{\prime} \text { (physiological dead space volume) }}{\text { Vt (tidal volume) }}=\frac{\mathrm{PaCO}_{2}-\mathrm{PE}_{\mathrm{CO}_{2}}}{\mathrm{PaCO}_{2}} \\
\mathrm{D}_{\mathrm{L}}=\frac{\dot{\mathrm{V}}_{\mathrm{CO}}}{\mathrm{PA}_{\mathrm{CO}}} .
\end{gathered}
$$

$\dot{\mathrm{V}}_{\mathrm{Co}}$ is the minute uptake of $\mathrm{CO}, \dot{\mathrm{V}}_{\mathrm{E}}$ is the total gas volume expired per minute, $F_{I}$ and $F_{E}$ are the inspired and expired concentrations of the gases indicated by subscripts, PAco is the alveolar tension of $\mathrm{CO}$, and $\mathrm{PaCO}_{2}$ and $\mathrm{PE}_{\mathrm{CO}_{2}}$ are arterial and expired tensions of $\mathrm{CO}_{2}$, respectively.

When the inspired mixture contained 5.0 per cent $\mathrm{CO}_{2}$,

$$
\mathbf{r}=\frac{\mathrm{PaCO}_{2}-\mathrm{PE}_{\mathrm{CO}_{2}}}{\mathrm{PaCO}_{2}-\mathrm{PICO}_{2}}
$$

Since $D_{L}$ is expressed as the quantity of $C O$ diffused per minute per $\mathrm{mm} . \mathrm{Hg} \mathrm{CO}$ pressure gradient between alveolar gas and capillary blood, the correct equation for $D_{\mathbf{L}}$ is $\frac{\dot{\mathrm{V}}_{\mathrm{CO}}}{\mathrm{PACO}_{\mathrm{A}}-\mathrm{Pc}_{\mathrm{CO}}}$, where $\mathrm{Pc}_{\mathrm{CO}}$ represents the mean carbon monoxide tension of pulmonary capillary blood. Filley and co-workers (3) regarded $\mathrm{P}_{\mathrm{CO}}$ as negligible and considered the pressure gradient substantially equal to the alveolar pressure of $\mathrm{CO}$, thus omitting $\mathrm{Pc}_{\mathrm{CO}}$ from the equation for expediency. In the present study, $\mathrm{Pc}_{\mathrm{co}}$ has been omitted from the equation and no correction for back pressure of $\mathrm{CO}$ was made in the calculations. This is not entirely correct for measurement of the absolute value of $D_{L}$, since it has been shown that Pcco does effect steady state determinations $(11,12)$, and repeated steady state measurements might be expected to show progressive decline in apparent $D_{L}$ because of the progressive accumulation of COHb. As pointed out previously, however, repeated measurements of $D_{L}$ at intervals of 20 minutes in control subjects in the resting state indicated that the $D_{L}$ was not being significantly altered, for the purposes of this study, by the changes in pulmonary capillary tension of $\mathrm{CO}$ brought about by preceding measurements.

Hyperventilation is one of the obvious consequences of exercise, and the effect on steady state $D_{L}$ of hyperventilation without other exercise was therefore examined. The procedure for measurement of $D_{L}$ by the steady state technique during hyperventilation requires description in some detail because of uncertainties which hyperventilation introduces into the method. The principal uncertainties are as follows:

1. The steady state method embodies the assumption that the physiological dead space and intrapulmonary distribution of carbon monoxide and carbon dioxide are similar, but it is uncertain how this relationship is affected by hyperventilation. However, the carbon monoxide dead space increases by about the same amount as that for carbon dioxide during the hyperpnea of exercise in normal persons (4), and it appears to be a reasonable assumption that this relationship also holds during voluntary hyperventilation. 
2. Hyperventilation also imposes significant technical difficulties: a) As the difference between $\mathrm{PaCO}_{2}$ and $\mathrm{PE}_{2}$ is progressively decreased by hyperventilation on air or, especially, on 5.0 per cent $\mathrm{CO}_{2}$, an error in the determination of either $\mathrm{PaCO}_{2}$ or $\mathrm{PE}_{\mathrm{CO}_{2}}$ will cause a progressively greater error in the determination of " $r$ " and, consequently, in $D_{\mathbf{L}}$. b) Failure to achieve a steady state may result in sampling which is unrepresentative of the entire test period with consequent possibility of large errors. In particular, overestimating mean $\mathrm{Paco}_{2}$ by about $4 \mathrm{~mm}$. $\mathrm{Hg}$ during hyperventilation on air could cause an apparent increase in $D_{\mathrm{L}}$ equal to that reported in Table $\mathrm{V}$ as resulting from hyperventilation. Underestimating $\mathrm{PaCO}_{2}$ causes $\mathrm{D}_{\mathrm{L}}$ to be underestimated, but the absolute error is less than that caused by overestimation of $\mathrm{PaCO}_{2}$. c) Failure to reach a steady state can cause some error even though ventilation rate and cardiac output are constant and arterial blood is sampled at a constant rate throughout the period of collecting expired air. This is because the $\mathrm{CO}_{2}$ dissociation curve is not a straight line, so that the pooled arterial sample, although it represents accurately the mean $\mathrm{CO}_{2}$ content of blood when this is changing during the collection period, may not represent exactly the mean $\mathrm{CO}_{2}$ tension. Sample calculations indicate, however, that the error on this account is negligible for present purposes.

Because of these uncertainties, care was taken to keep hyperventilation as regular as possible. The frequency of respiration was timed with a metronome at 22 breaths per minute and the subjects were asked to keep tidal volume as constant as possible. Hyperventilation was maintained on the carbon monoxide mixture for six minutes, during the last two minutes of which expired gas was collected and arterial blood was continuously drawn at a steady rate for the determination of $D_{L}$. This procedure was carried out for hyperventilation on 0.1 per cent $\mathrm{CO}$ in air as well as 0.1 per cent $\mathrm{CO}$ in a mixture with 5.0 per cent $\mathrm{CO}_{2}$. During these few minutes a condition of complete equilibrium was certainly not attained. For the six subjects of Table $\mathrm{V}$, the control respiratory exchange ratio was $\mathbf{0 . 9 6}$ (S.D., 0.13) and that during hyperventilation on air was 1.33 (S.D., 0.20). For the three subjects who also hyperventilated on 5.0 per cent $\mathrm{CO}_{2}$, the values at this time were $0.36,0.51$ and 0.67 . The question of importance for the present use of the steady state method, however, is the extent to which conditions were stable during the test period. To examine this question, end-expiratory alveolar air samples were collected from the first three subjects at the end of each test period and the $\mathrm{PACO}_{2}$ calculated from these samples was compared with the mean $\mathrm{PaCO}_{2}$ of the arterial blood sample which was drawn continuously through the two minutes of the test period. For the resting state, the values of arterial minus alveolar $\mathrm{pCO}_{2}$ were $-0.1,0.9$ and $-0.6 \mathrm{~mm}$. $\mathrm{Hg}$; for hyperventilation on air, they were $1.9,-0.1$ and $1.2 \mathrm{~mm}$. $\mathrm{Hg}$; and for hyperventilation on $\mathrm{CO}_{2}$, they were $-0.2,-0.2$ and 0.2 $\mathrm{mm}$. Hg. These results indicate that conditions during the test period were adequately steady for use of the method. As an additional check, the oxygen contents of inspired, expired and alveolar air were used for an independent calculation of " $r$ " and $D_{L}$. This precaution is especially desirable in experiments dealing with hyper- ventilation on $\mathrm{CO}_{2}$, since analytical errors in $\mathrm{CO}_{2}$ measurements here can cause large errors in estimation of $D_{L}$. As an auxiliary test gas, oxygen also has the advantages of being somewhat less sensitive than $\mathrm{CO}_{2}$ to variations in the steady state, and of having physical properties close enough to carbon monoxide to make it probable that intrapulmonary distribution of the two gases during hyperventilation is similar. Results with the two test gases were quite similar, as shown in Table $\mathrm{V}$, which presents $\mathrm{D}_{\mathrm{L}}$ values obtained during the same experiments using arterial $\mathrm{pCO}_{2}$, alveolar $\mathrm{pCO}_{2}$ and alveolar $\mathrm{pO}_{2}$. These all show substantial agreement.

These experiments indicate that the steady state method can be used satisfactorily during hyperventilation under the conditions of this investigation.

b) Breath holding technique. Measurements of the breath holding $\mathrm{D}_{\mathrm{L}}$ were made by the modification of the Krogh technique described by Forster and co-workers $(5,13)$. Using this technique, the subject made a maximal inspiration from the level of residual volume, held his breath for approximately 10 seconds with the glottis open, avoiding a valsalva maneuver, and then rapidly expired, delivering the entire expirate within two seconds. All of the expired air except the first liter, usually amounting to between 2.5 and $3 \mathrm{~L}$., was collected to be analyzed as alveolar gas. The inspired gas mixture contained 0.3 per cent carbon monoxide, 10 per cent helium and approximately 20 per cent oxygen in nitrogen and was inspired from a bag in a box connected with a Collins spirometer so that the inspired volume was recorded on the spirometer. The exact duration of breath holding, timed from the beginning of inspiration to the start of collection of the alveolar sample, was recorded on the spirometer kymograph drum, which was turning at a constant rate. The alveolar sample was collected through a stopcock in the circuit near the subject's mouth. After the subject expired approximately $1 \mathrm{~L}$. (as observed on the spirometer tracing), which was considered more than adequate to wash out the dead space, the stopcock was turned so that the remainder of the expirate was diverted into a collapsible plastic bag, previously evacuated to low pressure by a pump. Residual volume was determined in each subject by the open circuit helium method of Hickam, Blair and Frayser (14) and, since inspiration was made from residual volume, alveolar volume was taken as the sum of residual volume and inspired volume.

The alveolar gas samples were analyzed for helium, carbon monoxide and oxygen. The helium concentration was determined by katharometer ${ }^{2}$ with an accuracy of about one part in 100 or $\mathbf{0 . 0 5}$ per cent helium (14). Carbon monoxide concentration was measured by the infrared analyzer with an accuracy of about one part in 100 or 0.001 per cent carbon monoxide. Analyses for helium and carbon monoxide were made after removal of $\mathrm{CO}_{2}$ by passage through "ascarite." The helium and carbon monoxide concentrations obtained in this manner were then corrected for the volume change resulting from removal of carbon dioxide prior to analysis. In order to make this correction, determination of carbon dioxide con-

\footnotetext{
${ }^{2}$ Hastings Instrument Co.
} 
centration in the alveolar sample was required. This was done indirectly as follows. The oxygen concentration in the dried gas sample was determined by a Pauling analyzer, ${ }^{3}$ both before and after removal of carbon dioxide by passage through "ascarite." The carbon dioxide concentration could then be estimated by the change in oxygen content of the gas sample resulting from carbon dioxide absorption. Change in oxygen concentration can be measured, under these conditions, with an accuracy of 0.1 per cent. Estimate of carbon dioxide by this means is relatively crude, but is accurate to less than 0.5 per cent. This degree of inexactitude introduces an error of less than one part in 200 in the estimate of carbon monoxide and helium concentrations. In the helium analysis, allowance was made for the effect on the katharometer of changes in the oxygen-nitrogen ratio in the expired gas from the value

Initial CO concentration in the expired alveolar sample $=\frac{\mathrm{He} \text { concentration in the expired alveolar sample }}{\text { Inspired He concentration }}$

$D_{L}$ was then calculated from Krogh's equation (1):

$$
\mathrm{D}_{\mathrm{L}}=\frac{\text { Alveolar volume (S.T.P.D.) } \times 60}{\text { Time (seconds) } \times(\mathrm{Bp}-47)} \times \text { Natural } \log \frac{\text { Initial CO concentration in the expired alveolar sample }}{\text { Final CO concentration in the expired alveolar sample }}
$$

with $\mathrm{D}_{\mathrm{L}}$ expressed as ml. CO (S.T.P.D.) diffused per minute per $\mathrm{mm}$. $\mathrm{Hg} \mathrm{CO}$ tension.

Measurement of cardiac output and central venous pressure. Cardiac output was determined by the dye dilution technique (15), with central venous injection of the dye as described by Doyle, Wilson, Lepine and Warren (16), using T-1824. A No. 6 calibrated catheter was inserted through an antecubital vein and the end placed in the superior vena cava by fluoroscopic observation so that $\mathrm{T}-1824$, in 0.5 per cent solution, could be injected from a calibrated syringe into the central circulation. After the dye was injected, arterial blood samples were collected in $3 \mathrm{ml}$. siliconized tubes at two second intervals. The undiluted dyed serum from each two second sample was read on a Beckman DU spectrophotometer against a serum blank. The optical densities were plotted against time on semilogarithmic graph paper and all the points from the first appearance of the dye in the serum until recirculation began were used in construction of a curve. With exercise and with the cardiac output increased by drugs, from five to eight points were available for constructing the curve. Under all other conditions, from seven to 11 points were used. Calculations of the cardiac outputs were then made from the time-concentration curves (16).

Since the purpose of cardiac output measurements was to study the relationship of cardiac output to $D_{\mathfrak{L}}$, it would have been desirable to make the measurements of cardiac output at precisely the same time $D_{L}$ was being determined. This, however, would have required a second arterial puncture for the steady state procedure since an arterial blood sample for $\mathrm{pCO}_{2}$ determination was being withdrawn continuously throughout the two minute $\mathrm{D}_{\mathrm{L}}$ determination period. Dye injections and arterial sample collections for cardiac output determinations, therefore, were carried out immediately before the arterial blood for $\mathrm{pCO}_{2}$ was taken.

${ }^{3}$ Model E-2, Arnold O. Beckman Inc. at which the katharometer was calibrated (0.26). A decrease in the ratio caused an apparent decrease in helium concentration as measured by the katharometer, amounting to 0.17 per cent helium for a change in ratio from 0.3 to 0.2. The appropriate correction was made in each case.

For the studies in which the cardiac output was measured, the indwelling brachial artery needle and superior vena cava catheter were put in place at least 30 minutes before the tests were begun. At least 10 minutes were allowed between each determination of $D_{\mathbf{L}}$ by the breath holding method.

The carbon monoxide concentration present in the alveolar sample before any had been absorbed by the lungs was calculated from the dilution of helium by the equation of Forster and co-workers $(5,13)$ :

$X$ Inspired CO concentration.

When $D_{L}$ was determined by the breath holding technique, it was again technically not feasible to collect the arterial blood samples for cardiac output measurement at the precise time $D_{L}$ was being measured. For this reason, the procedures for measuring cardiac output were carried out in the 30 to 40 seconds immediately before $D_{L}$ determination. In order to maintain conditions comparable to those during the measurement of $\mathrm{D}_{\mathrm{L}}$, the breath was also held with glottis open during the injection of dye and the collection of arterial blood samples. The same technique was used each time a cardiac output was measured together with a breath holding $D_{L}$ under various experimental conditions.

The central venous pressure was measured by way of the superior vena cava catheter, using a Statham strain gage ( 0 to $25 \mathrm{~mm}$. $\mathrm{Hg}$ ), and was recorded by a direct writing recorder. The point of zero reference was arbitrarily taken at a position midway between the table surface and the fourth costochondral junction. The matter of primary interest was change in pressure rather than absolute value of pressure.

Exercise. Exercise was carried out while supine by having the subjects alternately flex and extend the legs rapidly, sliding the heels along the table top. The subjects exercised for six minutes for both steady state and breath holding studies.

Procedures for increasing cardiac output without exercise. Cardiac output was increased by drugs in six subjects studied by the steady state method and in 12 subjects studied by the breath holding technique. In three subjects of the steady state group, the cardiac output was increased by epinephrine, 0.17 to $0.19 \mu \mathrm{g}$. per $\mathrm{Kg}$. per minute, given by intravenous infusion over a 10 minute period before the $D_{L}$ and cardiac output were determined and maintained during these determinations. In the other 
TABLE I

Steady state $D_{L}$, cardiac output and ventilation rate, in 19 normal supine subjects at rest

\begin{tabular}{|c|c|c|c|c|c|c|}
\hline Subject & Age & $\underset{\substack{\text { Surface } \\
\text { Suce }}}{ }$ & $\begin{array}{c}\text { Number of } \\
\text { determinations }\end{array}$ & $\begin{array}{c}\text { Ventilation } \\
\text { rate** }\end{array}$ & $\begin{array}{l}\text { Cardiac } \\
\text { output }\end{array}$ & $D_{\mathbf{L}}$ \\
\hline & & $M .2$ & & \multirow{7}{*}{$\begin{array}{c}\text { L./min. } \\
8.1 \\
7.4 \\
6.5 \\
6.3 \\
6.7 \\
8.8 \\
7.8 \\
5.3 \\
4.7 \\
6.1 \\
5.8 \\
7.4 \\
4.7 \\
6.5 \\
5.0 \\
5.4 \\
6.8 \\
7.4 \\
7.6 \\
4.9 \\
5.8 \\
8.7 \\
7.6 \\
7.1\end{array}$} & \multirow{7}{*}{$\begin{array}{c}\text { L.min. } \\
7.8 \\
6.1 \\
6.8 \\
7.5 \\
9.3 \\
6.7 \\
6.4 \\
4.2 \\
6.7 \\
9.4 \\
10.0 \\
6.4 \\
6.1 \\
7.1 \\
5.4 \\
6.2 \\
6.7 \\
\\
6.1 \\
5.8 \\
6.0 \\
10.3 \\
7.7 \\
9.4\end{array}$} & \multirow{7}{*}{$\begin{array}{c}\text { ml. } / \text { min. } / m m . H_{8} \\
24.4 \\
32.4 \\
23.5 \\
24.6 \\
23.5 \\
21.9 \\
25.1 \\
19.6 \\
23.9 \\
21.7 \\
22.6 \\
22.0 \\
27.2 \\
19.9 \\
24.5 \\
24.6 \\
19.9 \\
22.0 \\
24.3 \\
21.3 \\
19.4 \\
29.2 \\
22.9 \\
23.6\end{array}$} \\
\hline $\begin{array}{l}\text { D. P. } \\
\text { R. D. }\end{array}$ & $\begin{array}{l}22 \\
25\end{array}$ & $\begin{array}{l}1.86 \\
1.96\end{array}$ & $\begin{array}{l}1 \\
2\end{array}$ & & & \\
\hline F. D. & 24 & 2.10 & 2 & & & \\
\hline $\begin{array}{l}\text { R. R. } \\
\text { S. S. }\end{array}$ & $\begin{array}{l}24 \\
22\end{array}$ & $\begin{array}{l}2.14 \\
1.70\end{array}$ & $\begin{array}{l}1 \\
2\end{array}$ & & & \\
\hline C. R. & 20 & 1.82 & 2 & & & \\
\hline H. S. & 22 & 1.72 & 2 & & & \\
\hline $\begin{array}{l}\text { S. W. } \\
\text { D. G. } \\
\text { C. W. } \\
\text { B. S. } \\
\text { R. R. } \\
\text { S. R. } \\
\text { B. C. } \\
\text { B. M. } \\
\text { J. F. } \\
\text { J. S. } \\
\text { F. A. } \\
\text { J. B. }\end{array}$ & $\begin{array}{l}23 \\
22 \\
24 \\
21 \\
26 \\
22 \\
23 \\
22 \\
23 \\
21 \\
21 \\
21\end{array}$ & $\begin{array}{l}1.97 \\
2.06 \\
1.87 \\
1.88 \\
1.75 \\
1.70 \\
2.00 \\
1.96 \\
1.86 \\
2.08 \\
1.76 \\
2.12\end{array}$ & $\begin{array}{l}1 \\
1 \\
1 \\
1 \\
1 \\
1 \\
1 \\
1 \\
1 \\
1 \\
1 \\
1\end{array}$ & & & \\
\hline Mean & 22.5 & 1.91 & & $6.6 \pm 1.2 \dagger$ & $7.0 \pm 1.4$ & $23.5 \pm 3.0$ \\
\hline
\end{tabular}

* All ventilation rates are in L. per minute S.T.P.D.

$\dagger$ Values following the means are standard deviations.

three subjects of the steady state group, and in all the 12 subjects where breath holding $D_{\mathrm{L}}$ was determined while the cardiac output was increased by drugs, the cardiac output was increased by a combination of atropine sulfate and norepinephrine, which has also been found effective in increasing cardiac output by Bryant, Combs and Warren (17). Atropine sulfate $(2.0 \mathrm{mg}$.) was given intravenously over a two minute period followed by an intravenous infusion of norepinephrine given at the rate of $8.0 \mu \mathrm{g}$. per minute over a six minute period before the determinations of $D_{L}$ and cardiac output were made and maintained during these determinations.

In some experiments, the cardiac output was increased by producing reactive hyperemia in the legs with arterial tourniquets (18). The tourniquets were 6 inch sphygmomanometer cuffs which were placed around the upper thighs, inflated, and maintained at a pressure of $200 \mathrm{~mm}$. $\mathrm{Hg}$ for 15 minutes. The pressure was relieved suddenly by an escape valve. This procedure, which acutely reduces peripheral resistance, will approximately double the resting cardiac output for about a minute.

Procedures intended to produce pulmonary vascular engorgement. The effect of procedures designed to increase the pressure in the pulmonary capillary bed on the steady state $D_{L}$ was studied in several subjects. The procedures used were rapid expansion of the plasma volume by intravenous infusion of human serum albumin solution and reduction in size of the peripheral vascular bed by norepi-

'Made by the David Clark Co., Inc., Worchester, Mass. nephrine infusion or by compression of the body by an aviator's "G suit."' Pulmonary vascular pressures were not measured. It has been found, however, that these procedures will increase central venous pressure in normal subjects by about the same amount that they increase pulmonary capillary and pulmonary artery pressures. Changes in central venous pressure (CVP) were therefore used as a rough index of change in pulmonary vascular pressures. The support for this concept is provided by the work of several different investigators. Doyle, Wilson, Estes and Warren found that pulmonary arterial and capillary pressures were increased by rapid infusion of saline solution (19) to about the same extent that such infusions increase central venous pressure (20). They concluded that the rise in pressure produced in this way is essentially the same throughout the central veins and pulmonary vessels, with maintenance of normal pressure gradient at a higher level. Fowler, Westcott, Scott and McGuire (21) found that norepinephrine infusion produced a rise in pulmonary capillary pressure, and, in the three subjects where it was measured, a similar increase in right atrial pressure. Wood, Lewis, Forster and Beckman $(22,23)$ found that inflation of a "full pressure half-suit" around the lower half of the body produced similar increases in central venous, right heart, pulmonary artery and pulmonary capillary pressures.

In the present study, four subjects had an infusion of between 400 and $500 \mathrm{ml}$. of 5.0 per cent serum albumin in physiological saline over a six minute period to produce 
pulmonary vascular engorgement while the steady state $\mathrm{D}_{\mathrm{L}}$ was being determined.

In three subjects, inflation of the $G$ suit over the lower half of the body was used alone to produce pulmonary vascular engorgement. An attempt was made to keep the suit inflated at high pressure (two pounds per square inch) to cause marked increase in the CVP for the entire six minute period of the steady state $D_{\mathrm{L}}$ measurement. This was uncomfortable, however, and therefore the pressure during this time was alternately applied and released at 15 second intervals.

Pulmonary vascular engorgement was produced in two subjects by a combination of norepinephrine infusion with $\mathrm{G}$ suit inflation. When the suit was inflated to 1.5 pounds per square inch, it was found that the CVP was at first elevated but then decreased gradually even though $G$ suit pressure was maintained. Bondurant, Hickam and Isley (24) observed this previously and used norepinephrine infusion to maintain the increase in CVP produced by G suit inflation. For this reason, norepinephrine infusion was added to $G$ suit inflation in these two subjects, and the CVP remained elevated throughout the six minute period.

In six subjects, a combination of $G$ suit inflation (1 to 1.5 pounds per square inch) and infusion of 300 to $400 \mathrm{ml}$. of 5.0 per cent serum albumin solution in saline over the six minute $D_{\mathbf{L}}$ determination period was used to cause pulmonary vascular engorgement. With this method, high central venous pressures were produced and maintained for the six minute period without causing significant discomfort.

\section{RESULTS}

\section{A. Studies with $D_{L}$ determined by the steady state method}

The studies in normal resting subjects are summarized in Tables I and II. Nineteen supine subjects had a mean $\mathrm{D}_{\mathrm{L}}$ of $23.5(\mathrm{SD} \pm 3.0) \mathrm{ml}$. per minute per $\mathrm{mm}$. Hg. Six other subjects in the seated position had a mean $\mathrm{D}_{\mathrm{L}}$ of $25.5 \pm 5.3$ $\mathrm{ml}$. per minute per $\mathrm{mm}$. Hg. In this group of subjects, the differences between seated and supine $D_{L}$ values are not significant.

TABLE II

Steady state $D_{L}$, ventilation and cardiac output in six normal seated subjects at rest

\begin{tabular}{lccccc}
\hline \hline Subject & Age & $\begin{array}{c}\text { Surface } \\
\text { area }\end{array}$ & $\begin{array}{c}\text { Ventila- } \\
\text { tion } \\
\text { rate }\end{array}$ & $\begin{array}{c}\text { Cardiac } \\
\text { output }\end{array}$ & DL \\
\hline & & $M .2$ & L./min. & L./min. & $\begin{array}{c}\text { ml. } / \text { min.l } \\
\text { mm. Hg }\end{array}$ \\
D. J. & 21 & 1.84 & 6.8 & 5.3 & 22.0 \\
F. D. & 24 & 2.14 & 5.8 & 7.2 & 23.5 \\
C. H. & 21 & 2.14 & 7.8 & 4.5 & 26.7 \\
R. C. & 23 & 2.02 & 7.9 & 8.4 & 35.8 \\
B. L. & 23 & 2.14 & 8.3 & 7.6 & 23.1 \\
J. C. & 23 & 1.79 & 6.5 & 9.5 & 22.0 \\
Mean & 22.5 & 2.01 & $7.2 \pm 0.9$ & $7.1 \pm 1.9$ & $25.5 \pm 5.3$ \\
\hline
\end{tabular}

Effect of exercise and increased cardiac output on the steady state $D_{L}$

Cardiac output and $\mathrm{D}_{\mathrm{L}}$ were measured simultaneously in six subjects, first at rest, then during exercise, and finally during a period when the cardiac output was increased by drugs while the subjects were otherwise at rest, as summarized in Table III (see Methods). With exercise, the mean cardiac output increased to $13.6 \pm 3.9 \mathrm{~L}$. per minute from the resting value of $7.7 \pm 1.6 \mathrm{~L}$. per minute, while the mean $D_{L}$ increased to $39.8 \pm 5.5 \mathrm{ml}$. per minute per $\mathrm{mm}$. $\mathrm{Hg}$ from the resting mean of $25.4 \pm 3.6 \mathrm{ml}$. per minute per $\mathrm{mm}$. Hg. When the cardiac output was comparably increased by drugs without change in the mean ventilation rate, there was no increase in $D_{\mathrm{L}}$ over the resting level.

In four subjects, the intravenous infusion of 400 to $500 \mathrm{ml}$. of 5.0 per cent human serum albumin in normal saline increased the mean cardiac output to $10.7 \pm 1.2 \mathrm{~L}$. per minute from $6.7 \pm 2.6 \mathrm{~L}$. per minute at rest before the infusion, but the mean $D_{L}$ remained substantially unchanged (Table IV).

In summary, exercise caused a striking increase in steady state $D_{L}$, but increasing the cardiac output to the same extent by drugs or albumin infusion did not change $D_{L}$.

\section{Effect of increased ventilation rate on the steady state $D_{L}$}

The effect of voluntary hyperventilation, carried out as previously described, on the steady state $D_{L}$ was studied in six subjects who were otherwise at rest (Table $\mathrm{V}$ ). The mean ventilation rate changed from $6.1 \pm 0.9$ to $16.0 \pm 3.6$ L. per minute, while the mean cardiac output remained essentially the same as at rest. The mean $D_{L}$ increased from the resting level of $22.3 \pm 2.2 \mathrm{ml}$. per minute per $\mathrm{mm} . \mathrm{Hg}$ to $38.3 \pm$ $7.1 \mathrm{ml}$. per minute per $\mathrm{mm}$. $\mathrm{Hg}$ with hyperventilation.

The first three subjects shown in Table V hyperventilated while breathing 0.1 per cent carbon monoxide in a mixture with 5.0 per cent carbon dioxide as well as while breathing 0.1 per cent carbon monoxide in air. Hyperventilation while breathing the carbon dioxide mixture prevented the arterial $\mathrm{pH}$ and $\mathrm{pCO}_{2}$ changes which occurred with hyperventilation on air, but the 
TABLE III

Steady state $D_{L}$, ventilation rate, cardiac output and oxygen uptake, in six supine subjects at rest, during exercise, and with the cardiac output increased by drugs

\begin{tabular}{|c|c|c|c|c|c|}
\hline Subject & Condition & M.V.* & $\mathrm{O}_{2}$ uptake & c.o.† & $\mathrm{D}_{\mathbf{L}}$ \\
\hline R. D. & $\begin{array}{l}\text { Rest } \\
\text { Exercise } \\
\text { Epinephrine }\end{array}$ & $\begin{array}{c}L . / \min . \\
7.4 \\
28.7 \\
6.7\end{array}$ & $\begin{array}{c}\text { ml./min. } \\
320 \\
1,350 \\
324\end{array}$ & $\begin{array}{c}L . / \min . \\
6.1 \\
19.7 \\
12.1\end{array}$ & $\begin{array}{c}\text { ml./min. } / \mathrm{mm} . \mathrm{Hg} \\
32.4 \\
37.0 \\
31.2\end{array}$ \\
\hline F. D. & $\begin{array}{l}\text { Rest } \\
\text { Exercise } \\
\text { Epinephrine }\end{array}$ & $\begin{array}{r}6.3 \\
20.1 \\
6.0\end{array}$ & $\begin{array}{l}295 \\
892 \\
231\end{array}$ & $\begin{array}{r}7.5 \\
14.3 \\
14.8\end{array}$ & $\begin{array}{l}24.6 \\
47.9 \\
23.3\end{array}$ \\
\hline S. S. & $\begin{array}{l}\text { Rest } \\
\text { Exercise } \\
\text { Atropine and norepinephrine }\end{array}$ & $\begin{array}{r}7.8 \\
17.4 \\
7.5\end{array}$ & $\begin{array}{l}306 \\
669 \\
342\end{array}$ & $\begin{array}{r}6.4 \\
9.8 \\
10.8\end{array}$ & $\begin{array}{l}25.1 \\
34.9 \\
20.7\end{array}$ \\
\hline C. R. & $\begin{array}{l}\text { Rest } \\
\text { Exercise } \\
\text { Atropine and norepinephrine }\end{array}$ & $\begin{array}{r}4.7 \\
13.9 \\
6.5\end{array}$ & $\begin{array}{l}220 \\
634 \\
302\end{array}$ & $\begin{array}{r}6.7 \\
10.2 \\
13.1\end{array}$ & $\begin{array}{l}23.9 \\
36.5 \\
28.1\end{array}$ \\
\hline H. S. & $\begin{array}{l}\text { Rest } \\
\text { Exercise } \\
\text { Atropine and norepinephrine }\end{array}$ & $\begin{array}{r}5.8 \\
14.2 \\
7.1\end{array}$ & $\begin{array}{l}263 \\
659 \\
296\end{array}$ & $\begin{array}{l}10.0 \\
11.3 \\
14.2\end{array}$ & $\begin{array}{l}22.6 \\
36.8 \\
20.5\end{array}$ \\
\hline F. D. & $\begin{array}{l}\text { Rest } \\
\text { Exercise } \\
\text { Atropine and norepinephrine }\end{array}$ & $\begin{array}{r}6.7 \\
17.4 \\
6.6\end{array}$ & $\begin{array}{l}290 \\
696 \\
288\end{array}$ & $\begin{array}{r}9.3 \\
16.1 \\
16.4\end{array}$ & $\begin{array}{l}23.5 \\
45.4 \\
24.0\end{array}$ \\
\hline Means & $\begin{array}{l}\text { Rest } \\
\text { Exercise } \\
\text { Drugs }\end{array}$ & $\begin{array}{r}6.5 \pm 1.1 \\
18.6 \pm 5.5 \\
6.7 \pm 0.5\end{array}$ & $\begin{array}{l}282 \pm 35.9 \\
817 \pm 277.0 \\
297 \pm 38.0\end{array}$ & $\begin{array}{r}7.7 \pm 1.6 \\
13.6 \pm 3.9 \\
13.6 \pm 2.0\end{array}$ & $\begin{array}{l}25.4 \pm 3.6 \\
39.8 \pm 5.5 \\
24.6 \pm 4.2\end{array}$ \\
\hline
\end{tabular}

* Minute ventilation.

$\dagger$ Cardiac output.

TABLE IV

Effect of procedures designed to increase pulmonary vascular pressures on the steady state $D_{L}$ in six supine subjects

\begin{tabular}{|c|c|c|c|c|c|}
\hline Subject & Condition & M.V. & c.O. & C.V.P.* & $\mathrm{D}_{\mathrm{L}}$ \\
\hline S. S. & $\begin{array}{l}\text { Rest } \\
\text { Albumin infusion } \\
\text { G suit and albumin infusion }\end{array}$ & $\begin{array}{l}\text { L./min. } \\
5.3 \\
6.8 \\
4.8\end{array}$ & $\begin{array}{l}\text { L./min. } \\
\quad 4.2 \\
9.6 \\
5.8\end{array}$ & $\begin{array}{c}m m . \mathrm{Hg} \\
3.5 \\
9.6 \\
17.0\end{array}$ & $\begin{array}{c}\text { ml. } / \text { min. } / m m . ~ \\
19.6 \\
22.1 \\
19.0\end{array}$ \\
\hline H. S. & $\begin{array}{l}\text { Rest } \\
\text { Albumin infusion } \\
G \text { suit and albumin infusion }\end{array}$ & $\begin{array}{l}7.4 \\
6.3 \\
5.4\end{array}$ & $\begin{array}{r}6.4 \\
11.7 \\
7.2\end{array}$ & $\begin{array}{r}-0.3 \\
3.3 \\
8.8\end{array}$ & $\begin{array}{l}22.0 \\
23.0 \\
26.0\end{array}$ \\
\hline J.F. & $\begin{array}{l}\text { Rest } \\
\text { Albumin infusion } \\
\text { G suit and albumin infusion }\end{array}$ & $\begin{array}{l}5.8 \\
4.6 \\
4.8\end{array}$ & $\begin{array}{l}6.0 \\
9.7 \\
6.1\end{array}$ & $\begin{array}{r}0.5 \\
4.5 \\
16.2\end{array}$ & $\begin{array}{l}19.4 \\
21.3 \\
20.2\end{array}$ \\
\hline J.S. & $\begin{array}{l}\text { Rest } \\
\text { Albumin infusion } \\
\text { G suit and albumin infusion }\end{array}$ & $\begin{array}{l}8.7 \\
8.3 \\
7.2\end{array}$ & $\begin{array}{l}10.3 \\
11.6 \\
12.7\end{array}$ & $\begin{array}{l}0.5 \\
3.2 \\
7.0\end{array}$ & $\begin{array}{l}29.2 \\
29.4 \\
33.4\end{array}$ \\
\hline F. A. & $\begin{array}{l}\text { Rest } \\
\text { G suit and albumin infusion }\end{array}$ & $\begin{array}{l}7.6 \\
7.2\end{array}$ & $\begin{array}{l}7.7 \\
6.3\end{array}$ & $\begin{array}{r}0.9 \\
12.9\end{array}$ & $\begin{array}{l}22.9 \\
21.2\end{array}$ \\
\hline J. B. & $\begin{array}{l}\text { Rest } \\
\text { G suit and albumin infusion }\end{array}$ & $\begin{array}{l}7.1 \\
8.9\end{array}$ & $\begin{array}{r}9.4 \\
10.3\end{array}$ & $\begin{array}{r}8.9 \\
23.0\end{array}$ & $\begin{array}{l}23.6 \\
31.3\end{array}$ \\
\hline Means & $\begin{array}{l}\text { Rest (first } 4 \text { subjects) } \\
\text { Albumin infusion } \\
\text { Rest (all } 6 \text { subjects) } \\
\text { G suit and albumin infusion }\end{array}$ & $\begin{array}{l}6.8 \pm 1.6 \\
6.5 \pm 1.5 \\
7.0 \pm 1.2 \\
6.4 \pm 1.6\end{array}$ & $\begin{array}{r}6.7 \pm 2.6 \\
10.7 \pm 1.2 \\
7.3 \pm 2.3 \\
8.1 \pm 2.8\end{array}$ & $\begin{array}{r}1.1 \pm 1.7 \\
5.2 \pm 3.0 \\
2.3 \pm 3.5 \\
14.2 \pm 5.9\end{array}$ & $\begin{array}{l}22.6 \pm 4.6 \\
24.0 \pm 3.7 \\
22.8 \pm 3.6 \\
25.2 \pm 6.1\end{array}$ \\
\hline
\end{tabular}

\footnotetext{
* Central venous pressure.
} 
TABLE V

Effect of changes in ventilation rate on the steady state $D_{L}$ in six supine subjects

\begin{tabular}{|c|c|c|c|c|c|c|c|}
\hline Subject & Condition & M.V. & c.o. & $\mathrm{pCO}_{2} *$ & $\begin{array}{l}(1) \dagger \\
D_{L}\end{array}$ & $\stackrel{(2) \dagger}{D_{\mathbf{L}}}$ & $\stackrel{(3) \dagger}{D_{L}}$ \\
\hline & & L./min. & L./min. & $m m . \mathrm{Hg}$ & \multicolumn{3}{|c|}{ ml./min./mm. $\mathrm{Hg}$} \\
\hline D. G. & $\begin{array}{l}\text { Rest } \\
\text { Air hypervent. } \\
\mathrm{CO}_{2} \text { hypervent. }\end{array}$ & $\begin{array}{r}6.5 \\
20.8 \\
22.5\end{array}$ & $\begin{array}{l}7.1 \\
8.1 \\
8.5\end{array}$ & $\begin{array}{l}38.4 \\
24.0 \\
42.7\end{array}$ & $\begin{array}{l}19.9 \\
45.7 \\
43.2\end{array}$ & $\begin{array}{l}20.0 \\
38.7 \\
45.3\end{array}$ & $\begin{array}{l}19.9 \\
49.2 \\
42.9\end{array}$ \\
\hline C. W. & $\begin{array}{l}\text { Rest } \\
\text { Air hypervent. } \\
\mathrm{CO}_{2} \text { hypervent. }\end{array}$ & $\begin{array}{r}5.0 \\
11.7 \\
19.5\end{array}$ & $\begin{array}{l}5.4 \\
5.8 \\
8.6\end{array}$ & $\begin{array}{l}38.8 \\
27.6 \\
46.5\end{array}$ & $\begin{array}{l}24.5 \\
29.1 \\
29.8\end{array}$ & $\begin{array}{l}21.9 \\
29.3 \\
30.6\end{array}$ & $\begin{array}{l}22.0 \\
29.4 \\
29.5\end{array}$ \\
\hline B. $S$. & $\begin{array}{l}\text { Rest } \\
\text { Air hypervent. } \\
\mathrm{CO}_{2} \text { hypervent. }\end{array}$ & $\begin{array}{r}5.4 \\
13.9 \\
17.8\end{array}$ & $\begin{array}{l}6.2 \\
6.4 \\
7.0\end{array}$ & $\begin{array}{l}40.5 \\
29.4 \\
46.8\end{array}$ & $\begin{array}{l}24.6 \\
41.4 \\
37.1\end{array}$ & $\begin{array}{l}26.1 \\
36.9 \\
36.0\end{array}$ & $\begin{array}{l}25.6 \\
43.3 \\
39.5\end{array}$ \\
\hline R. R. & $\begin{array}{l}\text { Rest } \\
\text { Air hypervent. }\end{array}$ & $\begin{array}{r}6.8 \\
12.1\end{array}$ & $\begin{array}{l}6.7 \\
7.3\end{array}$ & $\begin{array}{l}41.8 \\
28.9\end{array}$ & $\begin{array}{l}19.9 \\
27.9\end{array}$ & & \\
\hline C. R. & $\begin{array}{l}\text { Rest } \\
\text { Air hypervent. }\end{array}$ & $\begin{array}{r}6.1 \\
19.4\end{array}$ & $\begin{array}{l}9.4 \\
9.5\end{array}$ & $\begin{array}{l}39.3 \\
24.6\end{array}$ & $\begin{array}{l}21.7 \\
41.2\end{array}$ & & \\
\hline \multirow[t]{3}{*}{$\begin{array}{l}\text { R. D. } \\
\text { Means }\end{array}$} & $\begin{array}{l}\text { Rest } \\
\text { Air hypervent. } \\
\text { a) First } 3 \text { subjects }\end{array}$ & $\begin{array}{r}6.5 \\
18.3\end{array}$ & $\begin{array}{l}6.8 \\
6.9\end{array}$ & $\begin{array}{l}42.4 \\
28.6\end{array}$ & $\begin{array}{l}23.5 \\
44.5\end{array}$ & & \\
\hline & $\begin{array}{l}\text { Rest } \\
\text { Air hypervent. } \\
\mathrm{CO}_{2} \text { hypervent. }\end{array}$ & $\begin{array}{r}5.6 \\
15.5 \\
19.9\end{array}$ & $\begin{array}{l}6.2 \\
6.8 \\
8.0\end{array}$ & $\begin{array}{l}39.2 \\
27.0 \\
45.3\end{array}$ & $\begin{array}{l}23.0 \\
38.7 \\
36.7\end{array}$ & $\begin{array}{l}22.7 \\
35.0 \\
37.3\end{array}$ & $\begin{array}{l}22.5 \\
40.6 \\
37.3\end{array}$ \\
\hline & $\begin{array}{l}\text { b) All } 6 \text { subjects } \\
\text { Rest } \\
\text { Air hypervent. }\end{array}$ & $\begin{array}{r}6.1 \pm 0.9 \\
16.0 \pm 3.6\end{array}$ & $\begin{array}{l}6.9 \pm 1.2 \\
7.3 \pm 1.2\end{array}$ & $\begin{array}{l}40.2 \pm 1.5 \\
27.2 \pm 2.1\end{array}$ & $\begin{array}{l}22.3 \pm 2.2 \\
38.3 \pm 7.1\end{array}$ & & \\
\hline
\end{tabular}

* Arterial blood.

$\dagger \mathrm{D}_{\mathrm{L}}(1)$ is calculated using arterial blood $\mathrm{pCO}_{2}$ to determine " $\mathrm{r}$, " $\mathrm{D}_{\mathrm{L}}(2)$ is calculated using alveolar $\mathrm{pCO}_{2}$ to determine "r," and $\mathrm{D}_{\mathrm{L}}(3)$ is calculated using alveolar $\mathrm{pO}_{2}$ to determine "r."

effect on $D_{\mathbf{L}}$ was the same. For the reasons already discussed (see Methods), $D_{L}$ in these three subjects was calculated with " $r$ " determined using arterial blood $\mathrm{pCO}_{2}$, with " $\mathrm{r}$ " determined using alveolar $\mathrm{pCO}_{2}$, and with " $\mathrm{r}$ " determined using alveolar $\mathrm{pO}_{2}$. The values for $\mathrm{D}_{\mathbf{L}}$ calculated by the three different methods are in close agreement.

In summary, voluntary hyperventilation, whether on air or 5.0 per cent $\mathrm{CO}_{2}$, caused the same apparent increase in steady state $D_{L}$ as occurred with exercise which induced an equal rise in ventilation rate.

Effect on the steady state $D_{L}$ of procedures designed to increase pulmonary vascular pressures

A study was made of the effect on steady state $\mathrm{D}_{\mathrm{L}}$ of procedures designed to increase pulmonary vascular pressures by pulmonary vascular engorgement. The four subjects who received an intravenous infusion of $\mathbf{5 . 0}$ per cent human serum albumin in normal saline (Table IV) had a mean rise in central venous pressure of $4.1 \mathrm{~mm}$. $\mathrm{Hg}$, a concomitant rise in mean cardiac output to $10.7 \pm 1.2 \mathrm{~L}$. per minute from $6.7 \pm 2.6 \mathrm{~L}$. per minute at rest, and no change in mean ventilation rate. The mean $D_{\mathrm{L}}$ was $22.6 \pm 4.6 \mathrm{ml}$. per minute per $\mathrm{mm} . \mathrm{Hg}$ in the control period and $24.0 \pm 3.7 \mathrm{ml}$. per minute per $\mathrm{mm}$. $\mathrm{Hg}$ with the albumin infusion. In six subjects, inflation of a $\mathrm{G}$ suit, in combination with serum albumin infusion, produced a mean increase in central venous pressure of $11.9 \mathrm{~mm}$. Hg without significant change in mean ventilation rate or cardiac output. The mean $\mathrm{D}_{\mathrm{L}}$ was $22.8 \pm 3.6 \mathrm{ml}$. per minute per $\mathrm{mm}$. $\mathrm{Hg}$ at rest and $25.2 \pm 6.1 \mathrm{ml}$. per minute per $\mathrm{mm}$. $\mathrm{Hg}$ with the increased central venous pressure (Table IV). When these 10 instances in which pulmonary vascular engorgement was produced by either albumin infusion alone or $\mathrm{G}$ suit inflation with albumin infusion are considered together, a small but statistically significant increase in $\mathrm{D}_{\mathrm{L}}$, amounting to $2.0 \mathrm{ml}$. per minute per $\mathrm{mm}$. $\mathrm{Hg}(\mathrm{p}<.05)(25)$, was 
TABLE VI

Effect of procedures designed to increase pulmonary vascular pressures on the steady state $D_{L}$ in three supine subjects

\begin{tabular}{|c|c|c|c|c|c|c|}
\hline Subject & Condition & M.V. & C.o. & & C.V.P. & $\mathrm{D}_{\mathbf{L}}$ \\
\hline \multirow{3}{*}{ B. C. } & & L./min. & L./min. & \multirow{3}{*}{$\begin{array}{r}\text { up } \\
\text { down }\end{array}$} & $\mathrm{mm} . \mathrm{Hg}$ & ml./min./mm. $\mathrm{Hg}$ \\
\hline & $\begin{array}{l}\text { Rest } \\
\text { G suit* }\end{array}$ & $\begin{array}{r}7.6 \\
20.8\end{array}$ & $\begin{array}{l}6.1 \\
8.1\end{array}$ & & $\begin{array}{l}1.0 \\
3.3\end{array}$ & $\begin{array}{l}24.3 \\
43.3\end{array}$ \\
\hline & G suit and norepinephrine infusion & 14.8 & 7.2 & & 5.9 & 29.2 \\
\hline \multirow[t]{2}{*}{ B. $\mathrm{M}$. } & $\begin{array}{l}\text { Rest } \\
\text { G suit* }\end{array}$ & $\begin{array}{l}4.9 \\
8.1\end{array}$ & $\begin{array}{l}5.8 \\
4.2\end{array}$ & \multirow{2}{*}{ up } & $\begin{array}{r}-0.4 \\
7.3\end{array}$ & $\begin{array}{l}21.3 \\
28.8\end{array}$ \\
\hline & G suit and norepinephrine infusion & 13.1 & 5.5 & & 8.8 & 40.8 \\
\hline J. B. & $\begin{array}{l}\text { Rest } \\
\text { G suit* }\end{array}$ & $\begin{array}{l}7.1 \\
9.4\end{array}$ & $\begin{array}{l}9.4 \\
9.1\end{array}$ & $\begin{array}{r}\text { up } \\
\text { down }\end{array}$ & $\begin{array}{r}8.9 \\
26.1 \\
8.9\end{array}$ & $\begin{array}{l}23.6 \\
28.0\end{array}$ \\
\hline Mean & $\begin{array}{l}\text { Rest (first } 2 \text { subjects) } \\
\text { G suit and norepinephrine infusion } \\
\text { Rest ( } 3 \text { subjects) } \\
\text { G suit* }\end{array}$ & $\begin{array}{r}6.3 \\
14.0 \\
6.5 \\
12.8\end{array}$ & $\begin{array}{l}6.0 \\
6.4 \\
7.1 \\
7.1\end{array}$ & $\begin{array}{r}\text { up } \\
\text { down }\end{array}$ & $\begin{array}{r}0.3 \\
7.4 \\
3.2 \\
12.2 \\
3.8\end{array}$ & $\begin{array}{l}22.8 \\
35.0 \\
23.1 \\
33.4\end{array}$ \\
\hline
\end{tabular}

* With alternate application and release of pressure as described in Methods.

associated with the pressure elevation (Table IV). This increase in $D_{L}$ was not dependent upon an increase in ventilation rate, since ventilation was actually lower in most of the subjects during the period of pulmonary vascular engorgement than during the control period.

In two subjects who had a combination of $G$ suit inflation and norepinephrine infusion, mean CVP was increased by $7.1 \mathrm{~mm}$. $\mathrm{Hg}$ without change in the cardiac output (Table VI). The mean ventilation rate, however, also increased. Mean $D_{L}$ in these subjects increased from 22.8 ml. per minute per $\mathrm{mm}$. $\mathrm{Hg}$ at rest to $35.0 \mathrm{ml}$. per minute per $\mathrm{mm}$. $\mathrm{Hg}$.

The three subjects who were studied during $G$ suit inflation in which the pressure was alter. nately increased and decreased, as already described, had a significant rise in central venous pressure, but this was also accompanied by an increase in mean ventilation rate. $D_{L}$ increased from $23.1 \mathrm{ml}$. per minute per $\mathrm{mm}$. $\mathrm{Hg}$ at rest to $33.4 \mathrm{ml}$. per minute per $\mathrm{mm}$. $\mathrm{Hg}$ (Table VI).

In summary, various procedures designed to increase pulmonary capillary pressure by engorging the lungs with blood produced only minor changes in steady state $D_{\mathbf{L}}$ unless they also caused an increase in minute ventilation; $D_{L}$ showed a substantial increase only when ventilation was increased.
Effect of a combination of albumin infusion with increased ventilation on the steady state $D_{L}$

To investigate the possibility that increased pulmonary vascular pressures could enhance the effect of hyperventilation on $D_{L}$, three subjects were studied, first at rest, then with hyperventilation, and lastly with hyperventilation during an intravenous infusion of 400 to $500 \mathrm{ml}$. of 5.0 per cent human serum albumin in normal saline (Table VII). Hyperventilation alone, with a mean ventilation rate of $16.6 \mathrm{~L}$. per minute, increased mean $D_{L}$ to $37.9 \mathrm{ml}$. per minute per $\mathrm{mm}$. $\mathrm{Hg}$ from $21.7 \mathrm{ml}$. per minute per $\mathrm{mm}$. $\mathrm{Hg}$ at rest. About the same mean ventilation rate, $16.3 \mathrm{~L}$. per minute, accompanied by a $6.8 \mathrm{~mm}$. $\mathrm{Hg}$ increase in the central venous pressure produced by the albumin infusion, increased the

TABLE VII

Effect of a combination of albumin infusion with an increased ventilation rate on the steady state $D_{L}$ in three supine subjects

\begin{tabular}{|c|c|c|c|c|}
\hline Condition & M.V.* & C.O.* & C.V.P.* & $D_{\mathbf{L}}$ \\
\hline \multirow{4}{*}{$\begin{array}{l}\text { Rest } \\
\text { Hyperventilation on air } \\
\text { Hyperventilation on air } \\
\text { in combination with } \\
\text { albumin infusion }\end{array}$} & L./min. & L./min. & $m m . H g$ & $\underset{m m . H g}{\operatorname{ml} / \min . /}$ \\
\hline & 6.5 & 7.6 & -0.5 & 21.7 \\
\hline & 16.6 & 7.1 & -1.5 & 37.9 \\
\hline & 16.3 & 10.3 & 5.3 & 39.5 \\
\hline
\end{tabular}

* Mean values for three subjects. 
mean $\mathrm{D}_{\mathrm{L}}$ to $39.5 \mathrm{ml}$. per minute per $\mathrm{mm}$. $\mathrm{Hg}$, essentially the same increase as with hyperventilation alone.

In summary, albumin infusions, intended to produce pulmonary vascular engorgement, did not enhance the effect of hyperventilation on $D_{L}$, as measured by the steady state method.

\section{B. Studies with $D_{L}$ determined by the breath hold- ing technique}

As shown in Table VIII, 19 supine subjects had a mean $\mathrm{D}_{\mathrm{L}}$ of $35.7 \pm 8.4 \mathrm{ml}$. per minute per $\mathrm{mm}$. $\mathrm{Hg}$ at rest. Eight of these subjects, with a mean $\mathrm{D}_{\mathrm{L}}$ of $38.6 \pm 9.7 \mathrm{ml}$. per minute per $\mathrm{mm}$. $\mathrm{Hg}$ supine, had a mean $D_{L}$ of $34.8 \pm 5.9 \mathrm{ml}$. per minute per $\mathrm{mm}$. $\mathrm{Hg}$ when seated (Table IX). This value agrees closely with the mean $D_{L}$ of $31.7 \pm 4.4 \mathrm{ml}$. per minute per $\mathrm{mm}$. $\mathrm{Hg}$ which Ogilvie, Forster, Blakemore and Morton found in eight young male seated subjects (5). Three subjects (ages 10,10 and 8) were excluded from their group of 11 subjects in determining this mean, in order to make the group comparable to ours in age and size. In the present group of eight subjects, the difference between $D_{L}$ in the supine and seated positions is not statistically significant.

The procedures required to prepare the subject

TABLE VIII

Breath holding $D_{L}$ determinations in 19 normal supine subjects at rest

\begin{tabular}{lccccc}
\hline \hline Subject & Age & $\begin{array}{c}\text { Surface } \\
\text { area }\end{array}$ & $\begin{array}{c}\text { Number } \\
\text { of deter- } \\
\text { minations }\end{array}$ & $\begin{array}{c}\text { Mean } \\
\text { alveolar } \\
\text { volume }\end{array}$ & $\begin{array}{c}\text { Mean } \\
\text { D. }\end{array}$ \\
\hline & & $M .2$ & & $m l$. & $\begin{array}{c}\text { ml./min.l } \\
\text { mm. Hg }\end{array}$ \\
P. B. & 23 & 2.10 & 2 & 5,570 & 32.9 \\
H. S. & 22 & 1.72 & 4 & 4,450 & 35.0 \\
B. L. & 23 & 2.14 & 1 & 5,570 & 47.8 \\
C. H. & 21 & 2.14 & 4 & 5,090 & 39.4 \\
Jo. W. & 21 & 2.08 & 8 & 5,200 & 35.7 \\
C. W. & 24 & 1.87 & 4 & 3,850 & 30.0 \\
J. B. & 21 & 2.12 & 5 & 4,430 & 28.0 \\
J. P. & 22 & 2.04 & 4 & 5,110 & 52.4 \\
D. G. & 22 & 2.06 & 4 & 5,240 & 52.2 \\
J.C. & 23 & 1.86 & 4 & 3,780 & 29.8 \\
F. D. & 24 & 2.10 & 6 & 6,040 & 40.9 \\
R. C. & 23 & 2.02 & 4 & 6,050 & 44.2 \\
J. W. & 31 & 1.88 & 4 & 5,400 & 34.6 \\
L. W. & 23 & 2.28 & 4 & 4,900 & 30.1 \\
G.P. & 25 & 2.02 & 3 & 5,870 & 32.6 \\
J. O. & 23 & 1.79 & 3 & 4,440 & 31.1 \\
H. T. & 22 & 2.14 & 3 & 5,460 & 27.2 \\
S. S. & 22 & 1.70 & 3 & 3,490 & 22.8 \\
F. A. & 21 & 1.76 & 3 & 3,980 & 32.4 \\
Mean & 23 & 2.00 & & $4,940 \pm 785$ & $35.7 \pm 8.4$ \\
& & & & &
\end{tabular}

TABLE IX

Breath holding $D_{L}$ determinations in eight normal seated subjects at rest

\begin{tabular}{lccccc}
\hline \hline Subject & Age & $\begin{array}{c}\text { Surface } \\
\text { area }\end{array}$ & $\begin{array}{c}\text { Alveolar } \\
\text { volume }\end{array}$ & $\begin{array}{c}\text { Seated } \\
\text { DL }\end{array}$ & $\begin{array}{c}\text { Mean } \\
\text { supine } \\
\text { D.* }\end{array}$ \\
\hline & & $M .2$ & $m l$. & \multicolumn{2}{c}{ ml./min./mm. $\mathbf{H g}$} \\
C. H. & 21 & 2.14 & 4,700 & 32.2 & 39.4 \\
Jo. W. & 21 & 2.08 & 5,730 & 34.2 & 35.7 \\
C. W. & 24 & 1.87 & 4,140 & 27.9 & 30.0 \\
J. B. & 21 & 2.12 & 5,000 & 32.2 & 28.0 \\
T. P. & 22 & 2.04 & 5,380 & 40.4 & 52.4 \\
O. G. & 22 & 2.06 & 6,100 & 42.5 & 52.2 \\
J. C. & 23 & 1.86 & 4,380 & 27.8 & 29.8 \\
F. D. & 24 & 2.10 & 6,400 & 41.4 & 40.9 \\
Mean & 22 & 2.03 & $5,230 \pm 815$ & $34.8 \pm 5.9$ & $38.6 \pm 9.7$ \\
\end{tabular}

* From Table VIII.

for the collection of arterial blood samples and determination of cardiac output produce a small but unavoidable amount of discomfort. To study the effect of this discomfort and accompanying apprehension on the control level of $D_{L}$, the $D_{L}$ was determined in 11 subjects: $a$ ) before any procedures, $b$ ) immediately after the arterial needle and venous catheter were put in place, and $c$ ) after the usual 30 minute waiting period. Mean values were $39.0 \pm 8.0,40.0 \pm 10.1$ and $38.2 \pm 9.9 \mathrm{ml}$. per minute per $\mathrm{mm}$. $\mathrm{Hg}$, respectively, and are not significantly different.

\section{Effect of exercise and increased cardiac output on the breath holding $D_{L}$}

$D_{L}$ and cardiac output were determined in eight subjects while at rest, then during exercise, and finally at rest with cardiac output increased by drugs (Table $\mathrm{X}$ ). During exercise, mean cardiac output increased to $13.2 \pm 2.1 \mathrm{~L}$. per minute from $6.6 \pm 1.0 \mathrm{~L}$. per minute at rest while mean $D_{L}$ increased to $48.9 \pm 10.5 \mathrm{ml}$. per minute per $\mathrm{mm}$. $\mathrm{Hg}$ from $39.8 \pm 9.7 \mathrm{ml}$. per minute per $\mathrm{mm} . \mathrm{Hg}$ at rest. When the cardiac output was increased to $11.9 \pm 3.6 \mathrm{~L}$. per minute by drugs, however, the mean $\mathrm{D}_{\mathbf{L}}$ did not increase from the resting value.

Four of these subjects also had determinations of cardiac output and $\mathrm{D}_{\mathrm{L}}$ during exercise at the same time that their cardiac output was already increased by drugs to determine whether these drugs might have some action which would tend to prevent $\mathrm{D}_{\mathrm{L}}$ from increasing (Table XI). The result was not entirely clear-cut. In each sub- 
ject, exercise still caused an increase in $D_{L}$, although the increase was less than that produced by exercise before the administration of drugs.

The effect of increasing cardiac output by release of arterial tourniquets which had occluded blood flow to the lower extremities for the preceding 15 minutes was also investigated in three

TABLE $X$

Breath holding $D_{L}$, alveolar volume and cardiac output in eight supine subjects at rest, during exercise, and with the cardiac output increased by drugs

\begin{tabular}{|c|c|c|c|c|}
\hline Subject & Condition & $\begin{array}{c}\text { Alveolar } \\
\text { volume }\end{array}$ & c.o. & $D_{\mathbf{L}}$ \\
\hline & & & & $\underset{\operatorname{mm} . \mathbf{H g}}{\operatorname{ml} / \min . /}$ \\
\hline B. L. & $\begin{array}{l}\text { Rest } \\
\text { Exercise } \\
\text { Drugs* }\end{array}$ & $\begin{array}{l}5,570 \\
5,990 \\
5,890\end{array}$ & $\begin{array}{r}7.0 \\
12.4 \\
14.9\end{array}$ & $\begin{array}{l}47.8 \\
57.5 \\
49.6\end{array}$ \\
\hline C. H. & $\begin{array}{l}\text { Rest } \\
\text { Exercise } \\
\text { Drugs }\end{array}$ & $\begin{array}{l}5.040 \\
4,880 \\
4,950\end{array}$ & $\begin{array}{r}6.3 \\
13.3 \\
9.9\end{array}$ & $\begin{array}{l}38.0 \\
43.4 \\
40.7\end{array}$ \\
\hline Jo. W. & $\begin{array}{l}\text { Rest } \\
\text { Exercise } \\
\text { Drugs }\end{array}$ & $\begin{array}{l}4,750 \\
5,270 \\
5,410\end{array}$ & $\begin{array}{r}8.7 \\
15.9 \\
8.1\end{array}$ & $\begin{array}{l}33.1 \\
47.5 \\
33.1\end{array}$ \\
\hline C. W. & $\begin{array}{l}\text { Rest } \\
\text { Exercise } \\
\text { Drugs }\end{array}$ & $\begin{array}{l}3,760 \\
4,100 \\
3,500\end{array}$ & $\begin{array}{r}6.0 \\
12.4 \\
9.4\end{array}$ & $\begin{array}{l}28.4 \\
36.9 \\
27.4\end{array}$ \\
\hline T. P. & $\begin{array}{l}\text { Rest } \\
\text { Exercise } \\
\text { Drugs }\end{array}$ & $\begin{array}{l}5,100 \\
5,460 \\
5,160\end{array}$ & $\begin{array}{r}5.7 \\
11.5 \\
15.4\end{array}$ & $\begin{array}{l}52.5 \\
64.3 \\
45.2\end{array}$ \\
\hline F. D. & $\begin{array}{l}\text { Rest } \\
\text { Exercise } \\
\text { Drugs }\end{array}$ & $\begin{array}{l}6,080 \\
6,330 \\
6,150\end{array}$ & $\begin{array}{r}5.6 \\
16.7 \\
10.6\end{array}$ & $\begin{array}{l}39.7 \\
48.3 \\
42.3\end{array}$ \\
\hline D. G. & $\begin{array}{l}\text { Rest } \\
\text { Exercise } \\
\text { Drugs }\end{array}$ & $\begin{array}{l}4,780 \\
5,330 \\
5,030\end{array}$ & $\begin{array}{r}6.4 \\
10.5 \\
17.6\end{array}$ & $\begin{array}{l}50.8 \\
58.4 \\
53.7\end{array}$ \\
\hline J. C. & $\begin{array}{l}\text { Rest } \\
\text { Exercise } \\
\text { Drugs }\end{array}$ & $\begin{array}{l}3,930 \\
4,450 \\
4,060\end{array}$ & $\begin{array}{r}7.1 \\
13.1 \\
9.0\end{array}$ & $\begin{array}{l}28.0 \\
34.8 \\
29.0\end{array}$ \\
\hline Mean & $\begin{array}{l}\text { Rest } \\
\text { Exercise } \\
\text { Drugs }\end{array}$ & $\begin{array}{l}4,880 \pm 770 \\
5,230 \pm 740 \\
5,020 \pm 880\end{array}$ & $\begin{array}{r}6.6 \pm 1.0 \\
13.2 \pm 2.1 \\
11.9 \pm 3.6\end{array}$ & $\begin{array}{l}39.8 \pm 9.7 \\
48.9 \pm 10.5 \\
40.1 \pm 9.5\end{array}$ \\
\hline
\end{tabular}

* Atropine and norepinephrine administration as described in Methods.

subjects. As indicated in Table XII, the mean cardiac output was almost doubled, but there was little change in $D_{L}$.

In summary, breath holding $D_{L}$ was considerably increased, as expected, by exercise which doubled the cardiac output, but doubling the output by drugs or tourniquet release had little effect on $D_{L}$.
TABLE XI

Breath holding $D_{L}$ and cardiac output in four supine subjects at rest, during exercise, with cardiac output increased by drugs, and with exercise while the cardiac output was increased by drugs

\begin{tabular}{lcc}
\hline \hline \multicolumn{1}{c}{ Condition } & C.O.* & \multicolumn{1}{c}{$\mathrm{DL}_{\mathrm{L}^{*}}$} \\
\hline & L./min. & ml. $/ \mathrm{min}_{\mathrm{r}} / \mathrm{mm} . \mathrm{Hg}$ \\
Rest & $6.2 \pm 0.7$ & $42.8 \pm 11.3$ \\
Exercise & $13.0 \pm 2.7$ & $51.5 \pm 12.9$ \\
Drugs $\dagger$ & $13.2 \pm 4.0$ & $42.5 \pm 10.6$ \\
Exercise with drugs $\dagger$ & $16.6 \pm 2.6$ & $46.5 \pm 9.0$ \\
\hline
\end{tabular}

* Means of four subjects.

t Atropine and norepinephrine administration as described in Methods.

\section{Effect of increased ventilation rate on the breath holding $D_{L}$}

Even though the breath is being held during the determination of $D_{L}$, exercise is accompanied by an increase in ventilation rate in the period preceding the breath holding period. The possibility that increased ventilation before the breath holding period could change $D_{L}$ was studied by having five subjects hyperventilate for a period of five or six minutes immediately prior to the determination of $D_{L}$ (Table XIII). The mean $D_{\mathrm{L}}$ at rest was $36.4 \pm 8.0 \mathrm{ml}$. per minute per $\mathrm{mm} . \mathrm{Hg}$ and after hyperventilation was $35.5 \pm$ $7.4 \mathrm{ml}$. per minute per $\mathrm{mm}$. Hg. Ogilvie, Forster, Blakemore and Morton reported comparable results in a similar study (5).

\section{TABLE XII}

Effect of blood $p H$ changes on the breath holding $D_{L}$ in three supine subjects

\begin{tabular}{|c|c|c|c|}
\hline Condition & c.o.* & $\underset{\text { pH }}{\text { Arterial* }}$ & $\mathrm{DL}_{\mathrm{L}}^{*}$ \\
\hline & L./min. & & $\underset{m m . H g}{\operatorname{ml} . / m i n .}$ \\
\hline Rest & & 7.42 & 36.3 \\
\hline $\begin{array}{l}\text { Arterial tourniquets on the } \\
\text { lower extremities }\end{array}$ & 4.4 & 7.42 & 33.8 \\
\hline $\begin{array}{l}30-40 \text { seconds after the } \\
\text { tourniquets were released }\end{array}$ & 8.5 & 7.35 & 35.1 \\
\hline After $\mathrm{NH}_{4} \mathrm{Cl}$ administration & & 7.38 & 35.8 \\
\hline $\begin{array}{l}\text { Arterial tourniquets on the } \\
\text { lower extremities after } \\
\mathrm{NH}_{4} \mathrm{Cl} \text { administration }\end{array}$ & & 7.38 & 35.0 \\
\hline $\begin{array}{l}30-40 \text { seconds after the } \\
\text { tourniquets were released }\end{array}$ & & 7.34 & 37.8 \\
\hline
\end{tabular}

* Means of three subjects. 
TABLE XIII

Effect of increased ventilation rate on the breath holding $D_{L}$ in five supine subjects

\begin{tabular}{|c|c|c|c|}
\hline Condition & $\begin{array}{l}\text { Alveolar* } \\
\text { volume }\end{array}$ & C.O.* & $D_{L} *$ \\
\hline & $m l$. & L./min. & $\begin{array}{c}\text { ml./min./ } \\
\text { mm. } \mathrm{Hg}\end{array}$ \\
\hline $\begin{array}{l}\text { Rest } \\
\text { Hyperventilation } †\end{array}$ & $\begin{array}{l}4,460 \pm 880 \\
4,290 \pm 820\end{array}$ & $\begin{array}{l}7.0 \pm 1.2 \\
6.0 \pm 4.0\end{array}$ & $\begin{array}{l}36.4 \pm 8.0 \\
35.5 \pm 7.4\end{array}$ \\
\hline
\end{tabular}

* Means of five subjects.

$\dagger$ Hyperventilation for five to six minutes immediately before the breath holding period.

Effect of a combination of increased cardiac output and increased ventilation rate on the breath holding $D_{L}$

The breath holding $D_{L}$ was not changed by either increased ventilation rate prior to the test or increased cardiac output alone. To mimic exercise more closely, two subjects were studied, first at rest, then with cardiac output increased by drugs, and finally with hyperventilation while the cardiac output was increased by drugs. The mean $D_{L}$ did not change significantly when the mean cardiac output was increased from 6.0 to 10.1 L. per minute by drugs. With the mean cardiac output increased to $10.1 \mathrm{~L}$. per minute, the subjects hyperventilated for five or six minutes immediately prior to the breath holding period, but this also failed to change $D_{L}$ significantly.

Effect of blood $p H$ changes on the breath holding $D_{L}$

Exercise causes a reduction in the blood $\mathrm{pH}$, more in mixed venous than arterial blood. An attempt was made to simulate this change without actual exercise by the use of arterial tourniquets on the thighs and administration of $\mathrm{NH}_{4} \mathrm{Cl}$. Release of arterial tourniquets which have made the legs ischemic for 15 minutes not only increases the cardiac output (18), but also reduces blood $\mathrm{pH}$ because a large volume of hypoxic, relatively acidic, blood enters the venous side of the circulation from the previously occluded region (26). To reinforce this drop in $\mathrm{pH}$, subjects were also studied after they were prepared by the oral administration of $20 \mathrm{Gm}$. of $\mathrm{NH}_{4} \mathrm{Cl}$ during the course of the day before the last part of the experiment was carried out. $D_{L}$ and arterial blood $\mathrm{pH}$, therefore, were determined in three subjects: $a$ ) before arterial tourniquets were ap- plied to the lower extremities, $b$ ) while arterial tourniquets occluded blood flow to the lower extremities, c) within 30 to 60 seconds after release of the arterial tourniquets, and $d$ ) under all three of the aforementioned conditions after the administration of $\mathrm{NH}_{4} \mathrm{Cl}$. In this sţudy, as in the other studies where $\mathrm{pH}$ was determined in conjunction with the breath holding $D_{L}$, the arterial blood sample for $\mathrm{pH}$ determination was withdrawn from the indwelling arterial needle over the entire 10 second breath holding period. There appears to be no relation between $D_{L}$ and changes in arterial blood pH brought about by these procedures (Table XII). In addition, a trial was made in two subjects of the effect of maintaining the arterial blood $\mathrm{pH}$ above 7.50 by voluntary overbreathing during exercise. This procedure had no apparent effect on the increase in $D_{L}$ during exercise, as measured by the single breath method.

In summary, exercise causes a reduction in the blood $\mathrm{pH}$, but reduction of the blood $\mathrm{pH}$ by experimental methods did not increase the $D_{L}$ as does exercise. On the other hand, when the reduction in blood $\mathrm{pH}$, usually caused by exercise, was prevented by overventilation, the increase in $D_{L}$ with exercise was not altered.

\section{Effect of reduction in mixed venous blood oxygen content on the breath holding $D_{L}$}

Exercise reduces the oxygen content of mixed venous blood without much change in arterial blood oxygen. Conceivably, venous hypoxia could affect the diffusing capacity by changing the resistance of precapillary vessels in the lung and so changing the distribution of blood to the capillaries. To produce venous, but not arterial, hypoxia without exercise, the following procedure was employed. Two subjects breathed 10 per cent oxygen for 10 minutes, lowering the arterial blood oxygen saturation to between 60 and 70 per cent, as estimated by an ear oximeter, ${ }^{5}$ and presumably reducing the mixed venous blood oxygen. At the end of this time, for measurement of $D_{L}$ by the breath holding method, the subject made the usual full expiration followed by a maximal inspiration of the carbon monoxide mixture, which contained 21 per cent oxygen. For the 10 seconds of the measurement, before

\footnotetext{
'Waters Conley.
} 
significant recirculation occurred, this procedure achieved some degree of mixed venous hypoxia with substantially normal arterial blood oxygen saturation. This procedure, tried in two subjects, had a negligible effect on $D_{L}$, and increasing the cardiac output with drugs at the same time caused no further change. These results are comparable to the results of a similar experiment reported by Cander and Forster (27).

\section{DISCUSSION}

It is well established that exercise increases the pulmonary diffusing capacity. In this study, as in previously reported studies (1-5), exercise caused an increase in $D_{L}$, both breath holding and steady state, in all subjects where $D_{L}$ was determined before and during exercise; and, as others have also observed (5), there was a proportionally greater increase in the steady state $D_{L}$ than in breath holding $D_{L}$. The mechanism of this increase in $D_{L}$ with exercise was studied by measuring the apparent pulmonary diffusing capacity in situations where one or more of the effects of exercise were reproduced experimentally.

Krogh (1) suggested that change in a stagnant plasma layer in the capillaries could be the mechanism by which exercise increases $D_{L}$. Change in the capillary wall permeability or capillary size brought about by lung volume change was suggested by Barcroft (28) as an explanation for the increase in $D_{L}$ with exercise. Forster (29) has pointed out that it is reasonable to assume that the surface area of the capillary bed increases with exercise, either by dilatation of patent vessels or opening of previously closed ones, as a result of vasomotion or hemodynamic forces. Roughton (12) found that the volume of blood in the pulmonary capillary bed is increased with exercise.

The cardiac output increases during exercise and it has been considered that the increase in $D_{L}$ is dependent in some way upon this change. This factor was studied by increasing the cardiac output in subjects otherwise at rest and measuring $D_{L}$. The cardiac output was increased in groups of subjects by three somewhat different methods: $a$ ) drugs, $b$ ) albumin infusion, and $c$ ) release of arterial tourniquets previously occluding blood flow into the lower extremities. In this study, neither the breath holding nor steady state $D_{L}$ were increased when the cardiac output was increased by methods other than exercise. In one group (Table III), the mean cardiac output was the same during exercise as when drugs were given, but even though $D_{L}$ was markedly increased by exercise, $D_{L}$ did not increase over the resting level when the cardiac output was increased by drugs. In all, 67 simultaneous determinations of cardiac output and steady state $D_{L}$ were made in 24 subjects under different experimental conditions. There is no significant correlation between the two variables $(r=0.219)$. This is supported by the observation of Johnson, Stein and Kimbel (30) who found that the breath holding $D_{L}$ of several patients with increased cardiac output due to hyperthyroidism was not significantly different from the $D_{L}$ found when they had normal cardiac output after they were made euthyroid by therapy.

The effect of increasing pulmonary vascular (pulmonary arterial and capillary) pressure was also investigated. Increased pulmonary vascular pressure is probably not the cause of an increased $D_{L}$ with exercise since $D_{L}$ increases significantly with moderate exercise, whereas in normal man there is little or no increase in pulmonary arterial pressure with moderate exercise $(31,32)$. This study was made, however, to determine whether an increase in $D_{L}$ could be produced by procedures designed to increase pulmonary vascular pressures. With experiments in which the ventilation rate was substantially unchanged, increase in pulmonary vascular pressures, as reflected by a fairly large increase in the mean central venous pressure, was accompanied by only a small increase in the steady state $D_{L}$. Lewis, Forster and Beckman (23) did not find a significant increase in the breath holding $D_{L}$ with inflation of a $G$ suit.

Increases in ventilation rate, however, whether or not produced by exercise, were uniformly found to be associated with increases in steady state $D_{L}$. Hyperventilation alone, without any change in the cardiac output, was accompanied by an increase in steady state $D_{L}$ in all subjects studied, whether they hyperventilated while breathing air or 5 per cent $\mathrm{CO}_{2}$. The increase in steady state $D_{L}$ with hyperventilation in one group of subjects (Table V) was about the same 
as the increase produced by exercise in another group of subjects (Table III) where the increase in mean ventilation rate was nearly the same. There is a highly significant correlation ( $\mathrm{r}=$ 0.787 ) between steady state $D_{L}$ and ventilation rate in the 67 determinations on 24 subjects mentioned above in whom the correlation between $D_{L}$ and cardiac output was not significant. Taken alone, these data suggest that the effect of ventilation rate on steady state $D_{L}$ is sufficient to account for the increase in $D_{L}$ which occurs with exercise. Increases in breath holding $D_{L}$, however, also occur with exercise when the rate of ventilation cannot be a factor during the test period itself because the breath is being held. Hyperventilation before the breath holding period, to mimic the course of ventilation during exercise, was without effect on $D_{L}$. Similar results have been reported previously (5). It would appear that the increase in breath holding $\mathrm{D}_{\mathrm{L}}$ which occurs with exercise depends upon some mechanism other than increase in cardiac output or ventilation rate.

An attempt was made to enhance the effect of hyperventilation on $D_{L}$ by simultaneously increasing cardiac output or by producing pulmonary vascular engorgement. The increase in steady state $D_{L}$ produced by hyperventilation, however, was not enhanced by simultaneous pulmonary vascular engorgement. In addition, the breath holding $\mathrm{D}_{\mathrm{L}}$, which was not increased by hyperventilation alone before the test period, likewise failed to increase when hyperventilation was combined with increase in cardiac output caused by drugs.

Exercise reduces $\mathrm{pH}$ and $\mathrm{pO}_{2}$ and increases $\mathrm{pCO}_{2}$ of mixed venous blood. Conceivably, such changes could affect the precapillary vascular system of the lungs in such a way as to alter the distribution of blood and increase $D_{L}$. For this reason, the effect on the breath holding $D_{L}$ of changes in $\mathrm{pH}$ and gas content of mixed venous blood was studied in small groups of subjects. Reducing $\mathrm{pH}$ did not cause an increase in breath holding $\mathrm{D}_{\mathrm{L}}$ and, likewise, partially counteracting the acidosis of exercise by hyperventilation did not prevent an increase in $D_{L}$ from occurring with exercise. Forster and co-workers $(13,29)$ found only a slight increase in breath holding $\mathrm{D}_{\mathrm{L}}$ when 6.0 per cent $\mathrm{CO}_{2}$ was included in the in- spired mixture, but a more significant increase in breath holding $\mathrm{D}_{\mathrm{L}}$ of 20 per cent in nine subjects who had breathed 7.5 per cent $\mathrm{CO}_{2}$ for 10 minutes. Observations were also made on the effect of reducing mixed venous $\mathrm{pO}_{2}$. The breath holding $\mathrm{D}_{\mathrm{L}}$ was neither increased by the procedure which was designed to reduce the mixed venous $\mathrm{pO}_{2}$ while allowing a normal arterial $\mathrm{pO}_{2}$, nor by combination of this procedure with an increased cardiac output. The procedure which probably produced changes in the mixed venous blood most like those of exercise was the release of tourniquets from ischemic lower extremities, which increases cardiac output and releases blood with a reduced $\mathrm{pH}$ and $\mathrm{pO}_{2}$ and an increased $\mathrm{pCO}_{2}$ into the venous side of the circulation. This, however, failed to increase $D_{L}$ as measured by the breath holding method. Breath holding $D_{L}$ was determined about 30 to 40 seconds after release of tourniquets, and it is possible that the changes caused by this procedure were not present for sufficient time to increase $D_{L}$.

In summary, the breath holding $D_{L}$ was not increased significantly by any procedure except exercise, while the steady state $D_{L}$ was increased by hyperventilation alone to about the extent that it was increased by exercise with a similar ventilation rate.

There are other factors which are known to be important in determining the actual value of $D_{L}$, but are not applicable in this study. The values of $D_{L}$ reported here are for apparent pulmonary diffusing capacity of the lung as a whole, which includes the factors of resistance to passive diffusion of carbon monoxide through the "membrane" and resistance to reaction with hemoglobin. Roughton, Forster and co-workers (12, 33-36) have measured the reaction rate of $\mathrm{CO}$ with hemoglobin and devised a method for determining separately the diffusing capacity of the membrane $\left(D_{m}\right)$. While the reaction rate of $C O$ with hemoglobin must be determined in order to measure $D_{m}$, the apparent $D_{L}$ can be measured without consideration for kinetics of the $\mathrm{CO}+\mathrm{Hb}$ reaction, though it is obviously playing a part in the actual value obtained. The reaction rate of $\mathrm{CO}+\mathrm{Hb}$ would have been applicable in this study only if it were being considered as a possible mechanism by which exercise increases $D_{L}$ or if it were being changed by procedures used 
to mimic the effects of exercise. There is no indication that a significant change in reaction rate was produced in this way. Reaction rate can be affected by changes in mean $\mathrm{pO}_{2}$ of pulmonary capillary blood (37), but the present experimental procedures probably altered this little. In a normal subject breathing 21 per cent oxygen, the oxygen tension of pulmonary capillary blood probably increases so rapidly when the blood is exposed to alveolar gas tensions (38), that the mean capillary $\mathrm{pO}_{2}$ is not greatly altered by moderate changes in the $\mathrm{pO}_{2}$ of pulmonary arterial blood. Even if the mean capillary $\mathrm{pO}_{2}$ were calculated as the arithmetic mean of pulmonary arterial and systemic arterial blood $\mathrm{pO}_{2}$ the present experimental procedures would have produced little change. From the data in Table III, it can be calculated that the mean $\mathrm{A}-\mathrm{V}$ oxygen difference was 3.7 volumes per cent for subjects at rest, 6.0 during exercise, and 2.2 when the cardiac output was increased by drugs. For normal subjects these values would correspond to pulmonary arterial $\mathrm{pO}_{2}$ values of approximately 48,40 and $60 \mathrm{~mm} . \mathrm{Hg}$, respectively, $(\mathrm{pH}$ 7.30). The greatest difference in mean capillary $\mathrm{pO}_{2}$ between these groups should have been less than $10 \mathrm{~mm} . \mathrm{Hg}$, and the effect of this on the reaction rate of carbon monoxide with hemoglobin is negligible for present purposes (37).

Steady state $D_{L}$ determinations are influenced by the mixed venous $\mathrm{COHb}$ concentration (11, 12) and to determine $D_{L}$ as accurately as possible, this must be taken into account. The present study has been concerned primarily with factors which change $D_{L}$ rather than with the absolute value of $D_{L}$. For the reasons already given, therefore, "back pressure" does not seem to be significant in the interpretation of the results of this study and no correction was made for capillary pCO. In the case of the breath holding $\mathrm{D}_{\mathrm{L}}$, the effect of capillary pCO has also been found to be almost insignificant at near normal alveolar $\mathrm{O}_{2}$ tensions $(11,39)$.

The answer to the question of why $D_{\mathbf{L}}$ increases with exercise is incomplete. By these methods, changes in cardiac output and pulmonary vascular pressures are without significant effect. With the steady state method, ventilation rate is of great importance and in the use of this method for investigative purposes, con- sideration must be given to the effect of changes in ventilation rate. The mechanism by which increased ventilation rate causes an increase in steady state $D_{L}$ has not been determined. During exercise or with hyperventilation, the mean volume of the lung is somewhat increased and it has been suggested in the past that increase in lung volume is the mechanism by which exercise causes an increase in $D_{L}(28)$. Grape and Tyler (40) found that the steady state $D_{L}$ increased when the alveolar volume was increased, but the amount of rise they observed is not sufficient to account for the rise which occurs with exercise. Increased ventilation rate may possibly increase the steady state $D_{L}$ by causing an increase in the perfused area of the pulmonary capillary bed or by causing a more even ventilation-perfusion ratio throughout the lung (29). The data available from this study do not bear on these possibilities.

\section{SUMMARY}

1. A study has been made of the means by which exercise increases the pulmonary diffusing capacity for carbon monoxide $\left(D_{L}\right)$ in normal subjects, using both the steady state and breath holding techniques.

2. Increases in cardiac output produced by means other than exercise caused no significant change in $D_{L}$ as measured by either the steady state or breath holding technique.

3. Steady state $D_{L}$ was found to be very sensitive to the ventilation rate, and by hyperventilation alone, $D_{L}$ was increased as much as by exercise at the same minute ventilation. Breath holding $D_{L}$ was not affected by hyperventilation preceding the measurement.

4. Although the effect of increased ventilation rate could explain the increase in steady state $D_{L}$ with exercise, an adequate explanation for the increase in breath holding $D_{\mathbf{L}}$ which occurs during exercise was not obtained.

\section{REFERENCES}

1. Krogh, M. The diffusion of gases through the lungs of man. J. Physiol. (Lond.) 1915, 49, 271.

2. Lilienthal, J. L., Jr., Riley, R. L., Proemmel, D. D., and Franke, R. E. An experimental analysis in man of the oxygen pressure gradient from alveolar air to arterial blood during rest and exercise at sea level and at altitude. Amer. J. Physiol. 1946, 147, 199. 
3. Filley, G. F., MacIntosh, D. J., and Wright, G. W. Carbon monoxide uptake and pulmonary diffusing capacity in normal subjects at rest and during exercise. J. clin. Invest. 1954, 33, 530.

4. Bates, D. V., Boucot, N. G., and Dormer, A. E. The pulmonary diffusing capacity in normal subjects. J. Physiol. (Lond.) 1955, 129, 237.

5. Ogilvie, C. M., Forster, R. E., Blakemore, W. S., and Morton, J. W. A standardized breath holding technique for the clinical measurement of the diffusing capacity of the lung for carbon monoxide. J. clin. Invest. 1957, 36, 1.

6. Rosenthal, T. B. The effect of temperature on the $\mathrm{pH}$ of blood and plasma in vitro. J. biol. Chem. 1948, 173, 25.

7. Drabkin, D. L., and Austin, J. H. Spectrophotometric studies. II. Preparation from washed blood cells; nitric oxide hemoglobin and sulfhemoglobin. J. biol. Chem. 1935, 112, 51.

8. Van Slyke, D. D., and Neill, J. M. The determination of gases in blood and other solutions by vacuum extraction and manometric measurements. I. J. biol. Chem. 1924, 61, 523.

9. Van Slyke, D. D., and Sendroy, J., Jr. Studies of gas and electrolyte equilibria in blood. XV. Line charts for graphic calculations by the Henderson-Hasselbalch equation, and for calculating plasma carbon dioxide content from whole blood content. J. biol. Chem. 1928, 79, 781.

10. Dill, D. B., Daly, C., and Forbes, W. H. The $\mathrm{pK}^{\prime}$ of serum and red cells. J. biol. Chem. 1937, 117, 569.

11. Linderholm, $\mathrm{H}$. On the significance of $\mathrm{CO}$ tension in pulmonary capillary blood for determination of pulmonary diffusing capacity with the steady state $\mathrm{CO}$ method. Acta med. scand. 1957, 156, 413.

12. Roughton, F. J. W. Average time spent by blood in human lung capillary and its relation to the rates of $\mathrm{CO}$ uptake and elimination in man. Amer. J. Physiol. 1945, 143, 621.

13. Forster, R. E., Fowler, W. S., Bates, D. V., and Van Lingen, B. The absorption of carbon monoxide by the lungs during breath holding. J. clin. Invest. 1954, 33, 1135.

14. Hickam, J. B., Blair, E., and Frayser, R. An opencircuit helium method for measuring functional residual capacity and defective intrapulmonary gas mixing. J. clin. Invest. 1954, 33, 1277.

15. Hamilton, W. F., Moore, J. W., Kinsman, J. M., and Spurling, R. G. Studies on the circulation. IV. Further analysis of the injection method, and of changes in hemodynamics under physiological and pathological conditions. Amer. J. Physiol. 1932, 99, 534.

16. Doyle, J. T., Wilson, J. S., Lepine, C., and Warren, J. V. An evaluation of the measurement of the cardiac output and the so-called pulmonary blood volume by dye-dilution method. J. Lab. clin. Med. 1953, 41, 29.
17. Bryant, G. D. N., Combs, J. J., Jr., and Warren, J. V. Observations on the role of norepinephrine in circulatory adaptation. Clin. Res. 1958, 6, 130.

18. Warren, J. V., and Stead, E. A., Jr. Control of the cardiac output in man; studies on reactive hyperemia. Fed. Proc. 1947, 6, 223

19. Doyle, J. T., Wilson, J. S., Estes, E. H., and Warren, J. V. The effect of intravenous infusions of physiologic saline solution on the pulmonary arterial and pulmonary capillary pressure in man. J. clin. Invest. $1951,30,345$.

20. Warren, J. V., Brannon, E. S., Weens, H. S., and Stead, E. A., Jr. Effect of increasing the blood volume and right atrial pressure on the circulation of normal subjects by intravenous infusions. Amer. J. Med. 1948, 4, 193.

21. Fowler, N. O., Westcott, R. N., Scott, R. C., and McGuire, J. The effect of nor-epinephrine upon pulmonary arteriolar resistance in man. J. clin. Invest. 1951, 30, 517.

22. Wood, E. H. Personal communication.

23. Lewis, B. M., Forster, R. E., and Beckman, E. L. Effect of inflation of a pressure suit on pulmonary diffusing capacity in man. J. appl. Physiol. 1958, $12,57$.

24. Bondurant, S., Hickam, J. B., and Isley, J. K. Pulmonary and circulatory effects of acute pulmonary vascular engorgement in normal subjects. J. clin. Invest. 1957, 36, 59.

25. Snedecor, G. W. Statistical Methods Applied to Experiments in Agriculture and Biology. Ames, Iowa, Iowa State College Press, 1940.

26. Hickam, J. B. Hyperpnea following release of arterial tourniquets. Fed. Proc. 1952, 11, 69.

27. Cander, L., and Forster, R. E. Effects of varying alveolar oxygen tension upon pulmonary membrane diffusing capacity and pulmonary capillary blood volume in man (abstract). Amer. J. Physiol. 1955, $183,601$.

28. Barcroft, J. Features in the Architecture of Physiological Function. Cambridge, Cambridge University Press, 1938.

29. Forster, R. E. Exchange of gases between alveolar air and pulmonary capillary blood. Physiol. Rev. 1957, 37, 391.

30. Johnson, R. L., Jr., Stein, M. K., and Kimbel, R. Pulmonary capillary blood flow and diffusing capacity before and after successful treatment for hyperthyroidism. Fed. Proc. 1958, 17, 81.

31. Hickam, J. B., and Cargill, W. H. Effect of exercise on cardiac output and pulmonary arterial pressure in normal persons and in patients with cardiovascular disease and pulmonary emphysema. J. clin. Invest. 1948, 27, 10.

32. Riley, R. L., Himmelstein, A., Motley, H. L., Weiner, H. M., and Cournand, A. Studies of the pulmonary circulation at rest and during exercise in normal individuals and in patients with chronic pulmonary disease. Amer. J. Physiol. 1948, 152, 372. 
33. Roughton, F. J. W. The kinetics of the reaction $\mathrm{CO}+\mathrm{O}_{2} \mathrm{Hb}=\mathrm{O}_{2}+\mathrm{COHb}$ in human blood at body temperature. Amer. J. Physiol. 1945, 143, 609.

34. Forster, R. E., Roughton, F. J. W., Kreuzer, F., and Briscoe, W. A. Photocolorimetric determination of rate of uptake of $\mathrm{CO}$ and $\mathrm{O}_{2}$ by reduced human red cell suspensions at $37^{\circ} \mathrm{C}$. J. appl. Physiol. 1957, 11, 260.

35. Roughton, F. J. W., Forster, R. E., and Cander, L. Rate at which carbon monoxide replaces oxygen from combination with human hemoglobin in solution and in the red cell. J. appl. Physiol. 1957, 11, 269.

36. Roughton, F. J. W., and Forster, R. E. Relative importance of diffusion and chemical reaction rates in determining rate of exchange of gases in the human lung, with special reference to true diffusing capacity of pulmonary membrane and volume of blood in the lung capillaries. J. appl. Physiol. 1957, 11, 290.

37. Forster, R. E., Roughton, F. J. W., Cander, L., Briscoe, W. A., and Kreuzer, F. Apparent pulmonary diffusing capacity for $\mathrm{CO}$ at varying alveolar $\mathrm{O}_{2}$ tensions. J. appl. Physiol. 1957, 11, 277.

38. Riley, R. L., and Cournand, A. Analysis of factors affecting partial pressures of oxygen and carbon dioxide in gas and blood of lungs: Therapy. J. appl. Physiol. 1951, 4, 77.

39. Forster, R. E., Cohn, J. E., Briscoe, W. A., Blakemore, W. S., and Riley, R. L. A modification of the Krogh carbon monoxide breath holding technique for estimating the diffusing capacity of the lung; a comparison with three other methods. J. clin. Invest. 1955, 34, 1417.

40. Grape, B., and Tyler, J. M. The effect of altering lung volume on pulmonary diffusion of carbon monoxide. Clin. Res. 1958, 6, 313. 